Article

\title{
Antitumor Mechanism of the Essential Oils from Two Succulent Plants in Multidrug Resistance Leukemia Cell
}

\author{
Paola Poma ${ }^{1}$, Manuela Labbozzetta ${ }^{1}$, James A. McCubrey ${ }^{2}$, Aro Vonjy Ramarosandratana ${ }^{3}(\mathbb{C}$, \\ Maurizio Sajeva ${ }^{1, * \mathbb{D}}$, Pietro Zito ${ }^{1} \mathbb{D}$ and Monica Notarbartolo ${ }^{1, *}$ \\ 1 Department of Biological, Chemical and Pharmaceutical Science and Technology (STEBICEF), \\ University of Palermo, 90128 Palermo, Italy \\ 2 Department of Microbiology and Immunology, Brody School of Medicine at East Carolina University, \\ Greenville, NC 27858, USA \\ 3 Department of Plant Biology and Ecology, University of Antananarivo, P.O. Box 906, \\ Antananarivo 101, Madagascar \\ * Correspondence: maurizio.sajeva@unipa.it (M.S.); monica.notarbartolo@unipa.it (M.N.)
}

Received: 25 July 2019; Accepted: 23 August 2019; Published: 26 August 2019

\begin{abstract}
Drug resistance remains a major challenge in the treatment of cancer. The multiplicity of the drug resistance determinants raises the question about the optimal strategies to deal with them. Essential oils showed to inhibit the growth of different tumor cell types. Essential oils contain several chemical classes of compounds whose heterogeneity of active moieties can help prevent the development of drug resistance. In the present paper, we analyzed, by gas chromatography-mass spectrometry the chemical composition of the essential oil of the leaves of Kalanchoe beharensis obtained by hydrodistillation and compared the chemical composition of its essential oil with that of Cyphostemma juttae. Our results demonstrated the anticancer and proapoptotic activities of both species against acute myeloid leukemia on an in vitro model and its multidrug resistant variant involving NF-кB pathway. The essential oils of both species produced a significant decrease in many targets of NF- $\mathrm{KB}$ both at mRNA and protein levels. The results corroborate the idea that essential oils may be a good alternative to traditional drugs in the treatment of cancer, especially in drug resistant cancer.
\end{abstract}

Keywords: acute myeloid leukemia cell; Cyphostemma juttae; essential oil; Kalanchoe beharensis; multidrug resistance; NF- $\kappa \mathrm{B}$

\section{Introduction}

Clinical multidrug resistance is a multifactorial and heterogeneous process that strongly limits the efficacy of antitumor drugs. Drug resistance, especially in its multiple type (MDR), remains a major challenge in the treatment of cancer. Resistance can develop by numerous mechanisms, including decreased drug uptake, increased drug efflux, activation of detoxifying systems, activation of DNA repair mechanisms, evasion of drug-induced apoptosis, elevated autophagy, and/or altered drug metabolism [1]. One of the determining causes is the overexpression of multidrug efflux transporters, such as P-glycoprotein (P-gp), Multidrug Resistance Related Proteins (MRPs) or Breast Cancer Resistance Protein (BCRP) [2,3]. Moreover, loss of pro-apoptotic factors (e.g., p53 or Bax) or overexpression of anti-apoptotic factors, such as Bcl-2 or inhibitors of apoptosis proteins (IAPs) may interfere with the induction of tumor cell killing determining the inefficacy of anticancer drugs [4]. More recently, the constitutive expression of NF- $\mathrm{KB}$ factor was also related to MDR [5]. In acute myeloid leukemia (AML), constitutive NF- $\mathrm{kB}$ has been detected in more than $50 \%$ of cases, enabling leukemic 
cells to resist apoptosis and stimulate uncontrolled proliferation [6]. Therefore, NF-kB is considered as a poor prognostic factor in different types of cancer, and its inhibition can lead to pro-apoptotic signal activation and pro-survival response suppression $[7,8]$. All these observations demonstrate the importance of NF- $\mathrm{kB}$ as a therapeutic target [9]. The multiplicity of the drug resistance determinants raises the question about the optimal strategies to deal with them. There is a need for new agents that are more effective and able to bypass resistance with respect to conventional ones. In this context, essential oils (EOs) inhibit the growth of different tumor cell types. EOs contain several chemical classes of compounds whose heterogeneity of active moieties can help avoid the development of resistances. Previous works demonstrated that EOs, among others, have antitumor activities on different types of tumors, such as hepatocellular carcinoma, triple negative breast cancer $[10,11]$ and acute myeloid leukemia (AML) [12] all characterized by scarce responsiveness to chemotherapeutic drugs.

The genus Kalanchoe Adanson (Crassulaceae) contains approximately 150 species distributed mainly in Madagascar, South Africa, eastern Africa, and Asia. Kalanchoe can have diverse forms, such as shrubs, small trees, lianas and small epiphytes both having succulent leaves [13,14]. Half of Kalanchoe species are native to Madagascar [15]. Kalanchoe plants have had a long history in folk medicine, and according to Akulova-Barlow [16], some have been called "miracle leaf" for their remarkable healing properties. Cytotoxic activity was tested in tumor cell lines by Yamagishi [17] and Shirobokov [18] and indicated that the juice of 12 species has antiviral or neutralizing activity against viruses. A review by Milad et al. [19] reported that Kalanchoe spp. have several pharmacological activities, for example: Antiviral, sedative, antiulcer, immunomodulatory, antileishmanial, CNS depressant, anti-inflammatory, thyroid peroxidase inhibitor, cytotoxic, hepatoprotective, antioxidant, analgesic, anticonvulsant, antimicrobial, B cell development inhibitor, cardiovascular activity, antihyperglycemic, larvicidal and insecticidal. In contrast to the extensively studied herbaceous Kalanchoe species, Kalanchoe beharensis is a large evergreen shrub up to $3 \mathrm{~m}$ tall of the xerophytic bush in southern Madagascar [20,21]. The leaves of the plant locally known as "mongy" are used in traditional medicine as a laxative [22,23], and occasionally consumed by the ring-tailed lemur [24,25].

From the chemical point of view, Kalanchoe spp. are composed of flavonoid glycosides, anthocyanins, coumarins, bufadienlolides, triterpenoids, phenanthrenes, sterols, fatty acids and kalanchosine dimalate salt [19]. However, the single chemical study was done by Ghaly et al. [26], which reported the isolation of five different flavonoids from the methanolic extracts of K. beharensis (Figure 1). To the best of our knowledge, there are no papers published on $\mathrm{EO}$ in the whole genus Kalanchoe.

The genus Cyphostemma (Planch.) Alston (Vitaceae) includes about 150 species distributed in eastern and southern Africa and Madagascar, and some species are used in traditional medicine [27]. The antiproliferative effects of solvent extracts of some Cyphostemma spp. on HepG2 cell line have been reported by Opoku et al. [28]. Recently, Zito et al. [11] demonstrated that the EO of Cyphostemma juttae has antitumor activities in triple negative breast cancer cells (MDA-MB-231, SUM 149).

In the present paper we analyzed, by gas chromatography-mass spectrometry (GC-MS), the chemical composition of the essential oil of the leaves of Kalanchoe beharensis obtained by hydrodistillation (HD) and compared the chemical composition of its EO with that of Cyphostemma juttae. We also evaluated if the cytotoxic activity of both species against AML in vitro model and its MDR variant involved NF-KB pathway. Previous papers [29,30] highlighted that HL-60R cells are characterized by an overexpression of NF- $\mathrm{KB}, \mathrm{P}-\mathrm{gp}$ and IAPs. In particular, P-gp and IAPs are targets of NF- $\mathrm{KB}$ and are also involved in drug and apoptosis resistance. IAPs, which are endowed with different activities, have also shown a remarkable ability to block apoptosis induced by a wide spectrum of non-related triggers, including different anti-tumor agents [30,31]. For these reasons, we selected these $\mathrm{NF}-\mathrm{kB}$ target genes to investigate their expression after EOs treatment. 


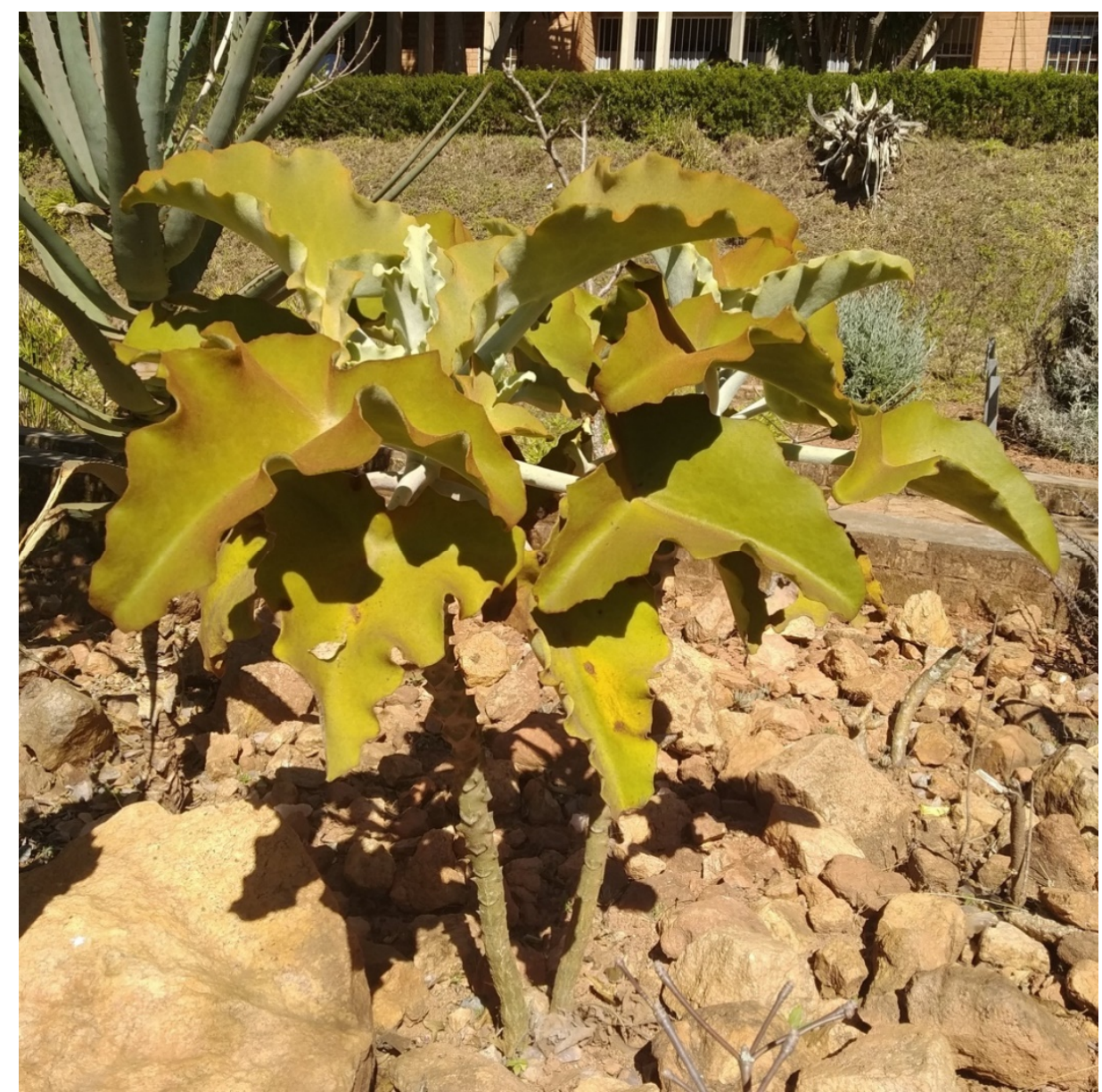

Figure 1. Kalanchoe beharensis cultivated at the Botanical Garden of the Department of Plant Biology and Ecology, University of Antananarivo (Photo V. Ramarosandratana).

\section{Results}

\subsection{Chemical Composition}

The essential oil yield was $15.21 \mathrm{mg}(0.003 \%)$. In the essential oil of Kalanchoe beharensis, we identified 57 compounds ( $87 \%$ of the whole composition) belonging to 14 different classes and functional groups of compounds (Table 1 ). Only compounds which had mass spectral similarity $\geq 80 \%$ with respect to our libraries were considered.

Overall, the composition was dominated by diterpene alcohols with $35.6 \%$, followed by aliphatic alkanes $(14.3 \%)$, aliphatic alcohols $(11.1 \%)$ and sesquiterpene hydrocarbons $(10.7 \%)$. The most abundant compounds ( $\geq 5 \%$ ) were phytol (35\%; Figure 2), tetradecanoic acid $(5.1 \%)$, $(Z, Z, Z)-9,12,15$-octadecatrien-1-ol (5.1\%), and heptacosane (5\%) contributing together $50.2 \%$ of the total composition. Eleven compounds were detected in relative amounts between 1 and $5 \%$, whereas 42 compounds were found in amounts $<1 \%$ (Table 1 ). 
Table 1. Essential oil composition of Kalanchoe beharensis. Compounds belonging to the same chemical class and functional group [32] are arranged according to Kovats Retention Indices (KRI) of the Supelcowax 10 column.

\begin{tabular}{|c|c|c|c|c|}
\hline $\mathrm{RI}^{\mathrm{a}}$ & Ident $^{b}$ & Compound & Relative Amount (\%) & MSS $^{\mathrm{c}}(\%)$ \\
\hline & & Aliphatic Acids & & \\
\hline 2720 & RI, MS & $\begin{array}{l}\text { Tetradecanoic Acid } \\
\text { Aliphatic Alcohols }\end{array}$ & 5.1 & 94 \\
\hline 1354 & RI, MS & Hexanol & 0.2 & 95 \\
\hline 1407 & RI, MS & (E)-2-Hexen-1-ol & 0.1 & 88 \\
\hline 1452 & RI, MS & 1-Octen-3-ol & 1.3 & 95 \\
\hline 1558 & RI, MS & Octanol & 1.5 & 97 \\
\hline 1616 & RI, MS & (E)-2-Octen-1-ol & 1.0 & 91 \\
\hline 1661 & RI, MS & Nonanol & 0.1 & 88 \\
\hline 1761 & MS & (Z)-9-Tetradecen-1-ol & 0.2 & 87 \\
\hline 1763 & RI, MS & Decanol & 0.1 & 87 \\
\hline 1968 & RI, MS & Dodecanol & 0.2 & 88 \\
\hline 2174 & RI, MS & Tetradecanol & 0.3 & 83 \\
\hline 2585 & RI, MS & Octadecanol & 0.4 & 90 \\
\hline 2793 & MS & Eicosanol & 0.8 & 91 \\
\hline 2816 & MS & $\begin{array}{c}(\mathrm{Z}, \mathrm{Z}, \mathrm{Z})-9,12,15-O c t a d e c a t r i e n-1-\mathrm{ol} \\
\text { Aliphatic Aldehydes }\end{array}$ & 5.1 & 85 \\
\hline 1050 & RI, MS & Hexanal & 0.5 & 92 \\
\hline 1218 & RI, MS & (E)-2-Hexenal & 0.7 & 95 \\
\hline 1389 & RI, MS & Nonanal & 0.4 & 96 \\
\hline 1494 & RI, MS & Decanal & 0.6 & 95 \\
\hline 2023 & RI, MS & Pentadecanal & 0.5 & 90 \\
\hline 2129 & RI, MS & $\begin{array}{c}\text { Hexadecanal } \\
\text { Aliphatic Alkanes* }\end{array}$ & 0.1 & 89 \\
\hline 1400 & RI, MS, Co-GC & Tetradecane & 0.1 & standard \\
\hline 1700 & RI, MS, Co-GC & Heptadecane & 0.04 & standard \\
\hline 1900 & RI, MS, Co-GC & Nonadecane & 0.2 & standard \\
\hline 2200 & RI, MS, Co-GC & Docosane & 0.4 & standard \\
\hline 2300 & RI, MS, Co-GC & Tricosane & 2.4 & standard \\
\hline 2500 & RI, MS, Co-GC & Pentacosane & 3.6 & standard \\
\hline 2600 & RI, MS, Co-GC & Hexacosane & 0.7 & standard \\
\hline 2700 & RI, MS, Co-GC & Heptacosane & 5.0 & standard \\
\hline 2900 & RI, MS, Co-GC & $\begin{array}{l}\text { Nonacosane } \\
\text { Aliphatic Alkenes }\end{array}$ & 1.8 & standard \\
\hline 1862 & MS & $\begin{array}{c}(Z, Z, Z)-3,6,9-\text { Tetradecatriene } \\
\text { Aliphatic Esters }\end{array}$ & 0.6 & 87 \\
\hline 1607 & RI, MS & Hexyl hexanoate & 0.1 & 86 \\
\hline 2213 & RI, MS & $\begin{array}{l}\text { Methyl palmitate } \\
\text { Aromatic Esters }\end{array}$ & 0.1 & 88 \\
\hline 2164 & MS & 2-Ethylhexyl benzoate & 0.1 & 93 \\
\hline 2286 & MS & $\begin{array}{l}\text { 2-Ethylhexyl salicylate } \\
\text { Diterpene Alcohols }\end{array}$ & 0.2 & 80 \\
\hline 2296 & RI, MS & Isophytol & 0.6 & 88 \\
\hline 2615 & RI, MS & $\begin{array}{l}\text { Phytol } \\
\text { Irregular terpene Ketones }\end{array}$ & 35.0 & 96 \\
\hline 1807 & RI, MS & $(E)-\beta$-Damascenone & 0.2 & 83 \\
\hline 2123 & RI, MS & $\begin{array}{l}\text { Hexahydrofarnesyl acetone } \\
\text { Monoterpene Alcohols }\end{array}$ & 4.1 & 94 \\
\hline 1789 & RI, MS & $\alpha$-Campholenol & 0.1 & 84 \\
\hline 2216 & RI, MS & $\begin{array}{c}\text { Carvacrol } \\
\text { Monoterpene Ketones }\end{array}$ & 0.2 & 91 \\
\hline 1630 & RI, MS & Pulegone & 0.5 & 95 \\
\hline 1908 & RI, MS & $\begin{array}{c}\text { Piperitenone } \\
\text { Sesquiterpene Alcohols }\end{array}$ & 0.6 & 86 \\
\hline 1552 & RI, MS & (Z)-Sesquisabinene hydrate & 0.2 & 86 \\
\hline 2042 & RI, MS & (E)-Nerolidol & 0.1 & 83 \\
\hline 2308 & MS & $\begin{array}{l}\text { 6-epi-Shyobunol } \\
\text { Sesquiterpene Ethers }\end{array}$ & 0.2 & 83 \\
\hline
\end{tabular}


Table 1. Cont.

\begin{tabular}{|c|c|c|c|c|}
\hline $\mathrm{RI}^{\mathrm{a}}$ & Ident $^{b}$ & Compound & Relative Amount (\%) & $\operatorname{MSS}^{\mathrm{c}}(\%)$ \\
\hline 1956 & RI, MS & $\begin{array}{l}\text { Caryophyllene oxyde } \\
\text { Sesquiterpene Hydrocarbons }\end{array}$ & 0.4 & 92 \\
\hline 1470 & RI, MS & $\alpha$-Copaene & 0.2 & 94 \\
\hline 1572 & RI, MS & $\beta$-Caryophyllene & 4.5 & 97 \\
\hline 1644 & RI, MS & $\alpha$-Humulene & 0.1 & 85 \\
\hline 1665 & MS & (E)- $\beta$-Bergamotene & 0.04 & 83 \\
\hline 1696 & RI, MS & $\gamma$-Humulene & 0.1 & 85 \\
\hline 1736 & RI, MS & $\delta$-Cadinene & 0.1 & 85 \\
\hline 1926 & RI, MS & Neophytadiene & 2.8 & 94 \\
\hline 1955 & MS & Neophytadiene isomer \# & 1.1 & 95 \\
\hline 1982 & MS & Neophytadiene isomer \# & 1.4 & 95 \\
\hline 2236 & MS & Neophytadiene isomer \# & 0.3 & 86 \\
\hline
\end{tabular}

${ }^{a} \mathrm{RI}=$ Experimental for Supelcowax 10 capillary column ( $30 \mathrm{~m}$ long, $0.25 \mathrm{~mm}$ i.d., $0.25 \mu \mathrm{m}$ film thickness). ${ }^{\mathrm{b}}$ Ident.: RI = NIST Standard Reference Database for polar capillary columns; MS = identification based on comparison of Mass Spectra; $\mathrm{Co}-\mathrm{GC}=\mathrm{Co}-$ injection of authentic compounds. ${ }^{\mathrm{C}}$ MSS: Mass Spectrum Similarity. ${ }^{\#}$ isomer not identified.

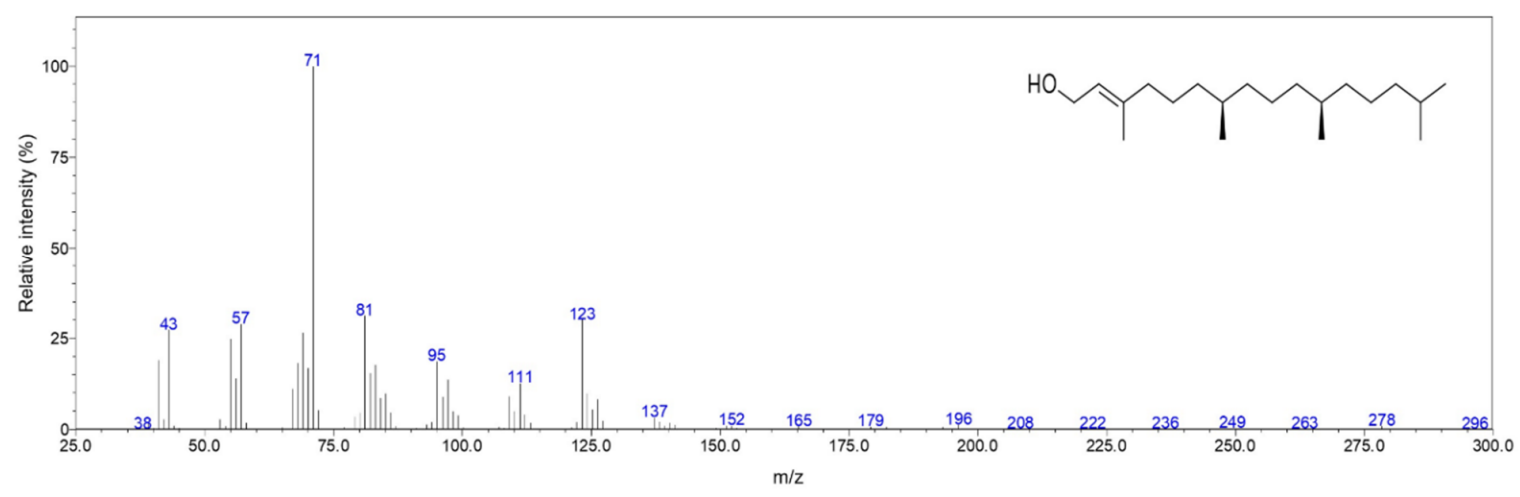

Figure 2. Mass spectrum and chemical structure of phytol found in the present study.

Zito et al. [11] found that the EO of C. juttae contained $34.2 \%$ of phytol and its isomer, while in the present study, K. beharensis contains $35 \%$ of phytol. Interestingly, also sesquiterpene hydrocarbons were present in both species with high percentages (10.6\% in K. beharensis and $13.9 \%$ in C. juttae) (Figure 3).

\subsection{Cytotoxic Effects of C. juttae and K. beharensis Essential Oils}

Cell growth inhibition assays revealed that the cytotoxic activity of $C$. juttae and K. beharensis essential oils on HL-60 cell line and on its MDR variant HL-60R cell line is quite equivalent. As shown in Figure 4A,B after $72 \mathrm{~h}$ of treatment, both essential oils induced cell growth inhibition at concentration-dependent way in the two cell lines; in Table 2 are reported the $\mathrm{IC}_{50}$ of $C$. juttae and $K$. beharensis essential oils. The treatment of the cell lines with doxorubicin, which is a conventional chemotherapeutic agent used as a first line treatment in $\mathrm{AML}$, caused a cytotoxic effect with $\mathrm{IC}_{50}$ values of $8 \pm 0.4 \mathrm{ng} / \mathrm{mL}$ and $1.2 \pm 0.3 \mu \mathrm{g} / \mathrm{mL}$ for HL-60 and HL-60R, respectively. The $\mathrm{IC}_{50}$ values of EOs in both cell lines are very similar, while as expected doxorubicin must be present at very high concentrations to obtain $\mathrm{IC}_{50}$. For this reason, we suppose that EOs were not substrates of P-gp as doxorubicin is. 


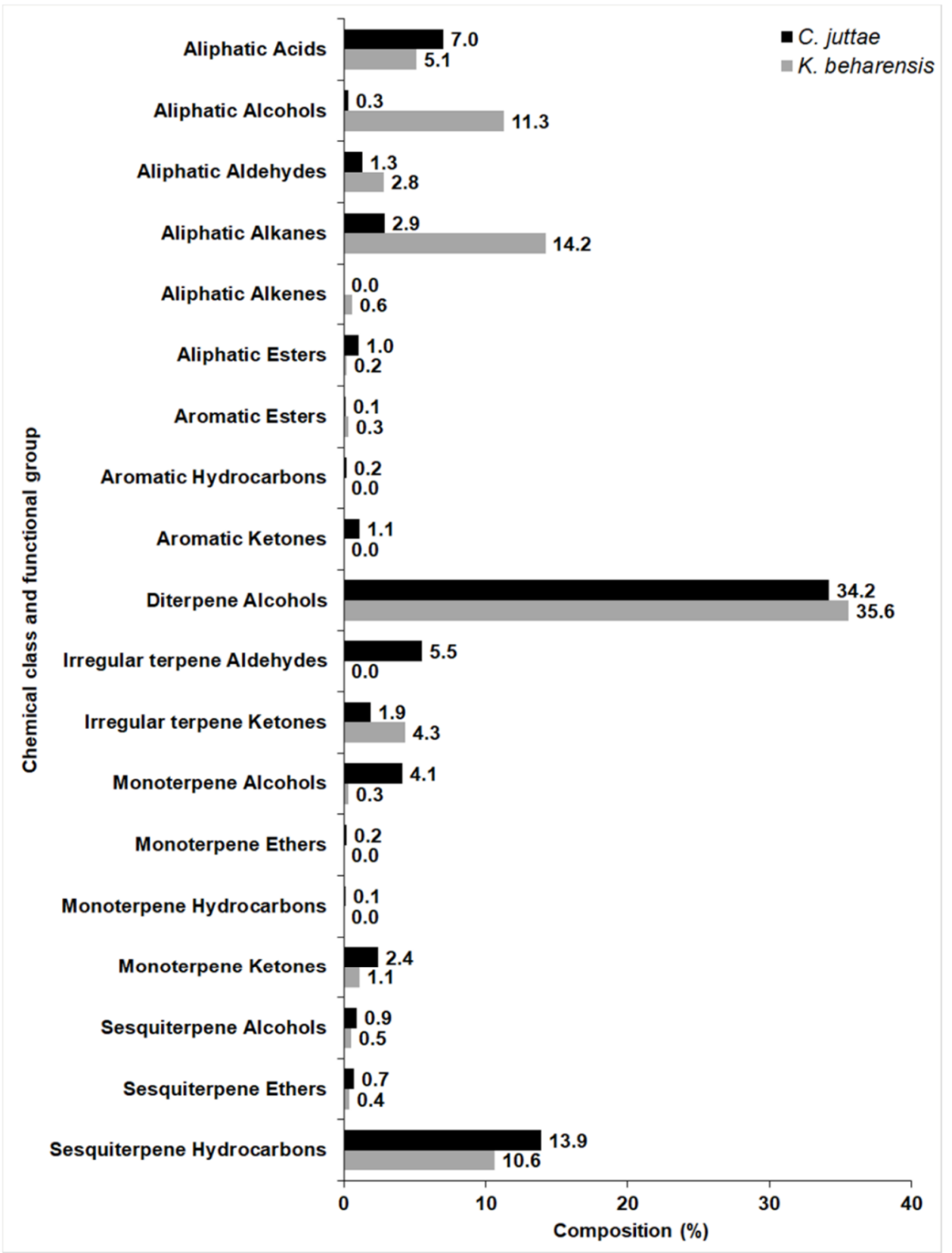

Figure 3. Relative (\%) amounts of each chemical class and the functional group identified in Cyphostemma juttae and K. beharensis.

Table 2. $\mathrm{IC}_{50}$ values of the two cell lines treated with the essential oils of $\mathrm{C}$. juttae and $\mathrm{K}$. beharensis.

\begin{tabular}{ccc}
\hline & HL-60 & HL-60R \\
\hline & IC $_{\mathbf{5 0}}$ & IC $_{\mathbf{5 0}}$ \\
\hline C. juttae EO & $22.0 \pm 0.3 \mu \mathrm{g} / \mathrm{mL}$ & $36 \pm 1.2 \mu \mathrm{g} / \mathrm{mL}$ \\
\hline K. beharensis EO & $25.0 \pm 0.6 \mu \mathrm{g} / \mathrm{mL}$ & $36.5 \pm 0.3 \mu \mathrm{g} / \mathrm{mL}$ \\
\hline
\end{tabular}



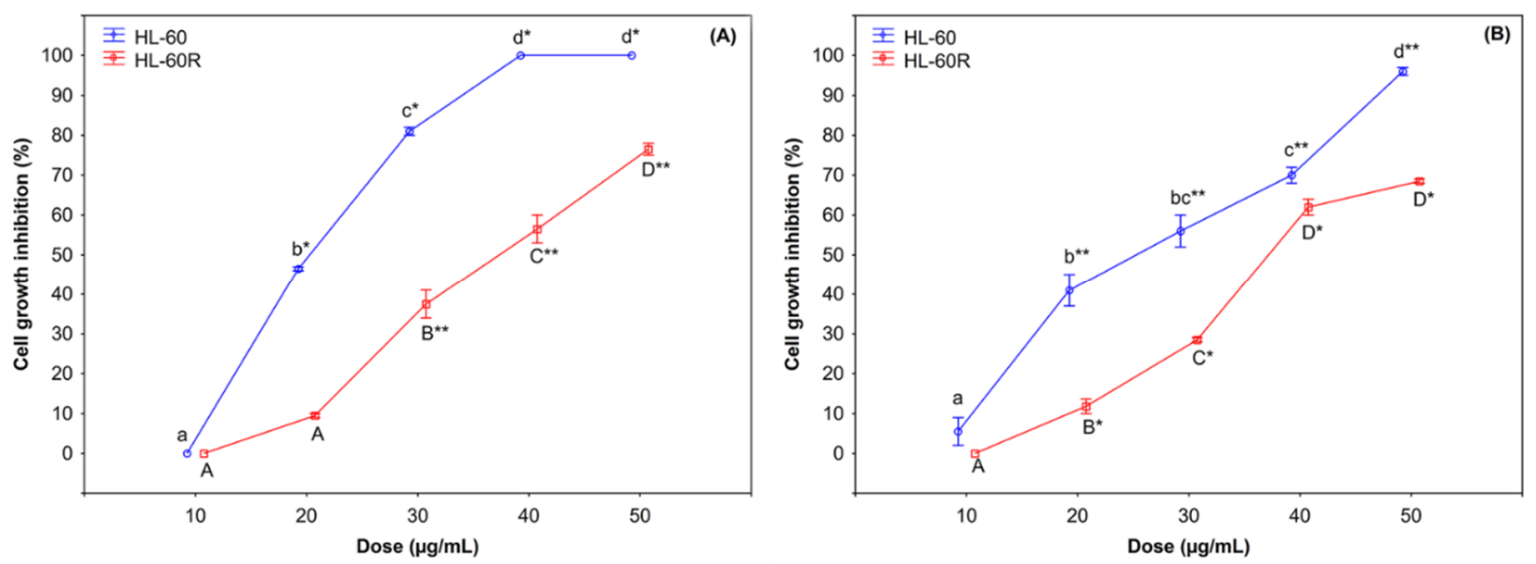

Figure 4. Cytotoxic activity of C. juttae (A) and K. beharensis (B) essential oils (Eos) on leukemia HL-60 and HL-60R cell lines. Cell viability was assessed by MTS. Data are expressed as mean \pm standard error of at least three different experiments performed in triplicate. Different letters represent significant differences (Tukey test) in cytotoxic activity among the concentrations of each cell line (C. juttae: HL-60 $p<0.01$ and HL-60R $p<0.05$; K. beharensis: HL-60 $p<0.05$ and HL-60R $p<0.01$ ). Differences when treatments are compared to the controls: ${ }^{*} p<0.05 ;{ }^{* *} p<0.01$.

The results on cell death were confirmed by flow cytometry assessments (Figure 5). The HL-60 and HL-60R cell lines were incubated with the essential oils $(40 \mu \mathrm{g} / \mathrm{mL})$ of $C$. juttae or K. beharensis for $24 \mathrm{~h}$, and thereafter, cell death was evaluated by flow cytometry analysis of cell DNA stained with propidium iodide. The results are in agreement with the cytotoxicity data, highlighting that both oils are capable of inducing cell death even in MDR variant cell line. In particular, the essential oil of $K$. beharensis caused a marked block in the preG $_{0}-\mathrm{G}_{1}$ position comparable in HL-60 and HL-60R cells (Figure 6).

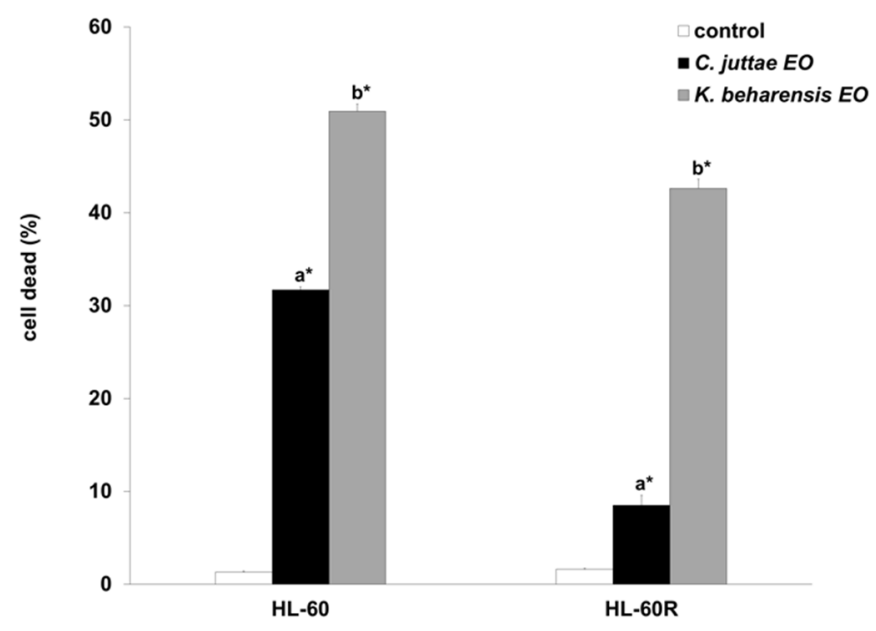

Figure 5. Induction of cell death by C. juttae or K. beharensis oils in HL-60 and HL-60 R cells. 

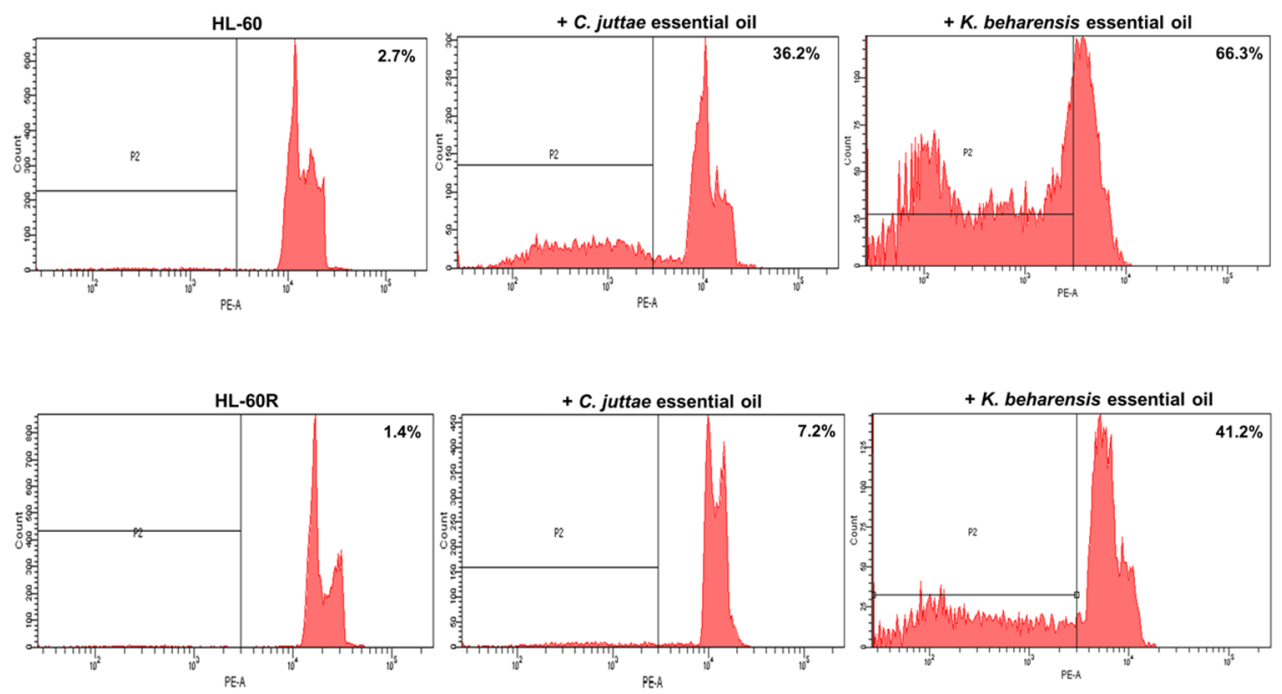

Figure 6. A representative example of flow cytometry analysis of cell death and cell cycle in the HL-60 and HL-60 R cells treated with $40 \mu \mathrm{g} / \mathrm{mL}$ concentrations of $C$. juttae or $K$. beharensis essential oils.

The cells were incubated with $40 \mu \mathrm{g} / \mathrm{mL}$ concentrations of $C$. juttae or K. beharensis essential oil for $24 \mathrm{~h}$ and thereafter cell death was evaluated by flow cytometry analysis of cell DNA stained with propidium iodide. Data are the mean \pm standard error of three separate experiments. Different letters represent significant differences in cytotoxic activity among the two essential oils of each cell line (HL-60 $p<0.01$; HL-60 R $p<0.01$ ). *Differences when treatments are compared to the control $p<0.01$ (Tukey test).

The figure shows the profiles of propidium iodide stained DNA. Numbers in the panels indicate the $\%$ of the events in the $\operatorname{preG}_{0}-\mathrm{G}_{1}$ position.

\subsection{Effects of Essential Oils on NF-אB (p65 subunit) Pathway in HL-60/HL-60R Cells}

In order to evaluate if $C$. juttae and K. beharensis essential oils could interfere on NF-kB DNA binding capacity, HL-60 and HL-60R cell lines were treated with the two essential oils at a concentration of $40 \mu \mathrm{g} / \mathrm{mL}$ for $24 \mathrm{~h}$.

According to the results previously published [29], the HL-60 cells showed a very slight DNA binding capacity of the p65 subunit. Otherwise, the HL-60R cells showed remarkable levels of the activated p65 subunit and both essential oils of $C$. juttae and K. beharensis determined a considerable decrease of its binding capacity to the corresponding DNA consensus sequence (Figure 7).

The cells were treated for $24 \mathrm{~h}$ with $C$. juttae or K. beharensis essential oils $(40 \mu \mathrm{g} / \mathrm{mL})$. Results (mean \pm standard error of two experiments carried out in duplicate) are expressed as arbitrary units/ $\mathrm{gg}$ protein of cells nuclear extracts. Different letters represent significant differences $(p<0.05)$ among the two essential oils. *Differences when treatments are compared to the control $p<0.01$ (Tukey test).

Given these results, we investigated if the treatment with essential oils at the same conditions also modified the expression of some NF- $\mathrm{KB}$ targets, at mRNA and protein levels in the MDR variant cell line. The most considerable result indicated a strong reduction in some IAPs as survivin and XIAP, Bcl-2 and P-gp expression by both essential oils (Figure 8). These results are also confirmed at protein levels; essential oils of $C$. juttae and $K$. beharensis, in fact, produced a strong reduction of the three anti-apopototic proteins, more evident for C. juttae EO (Figure 9). 


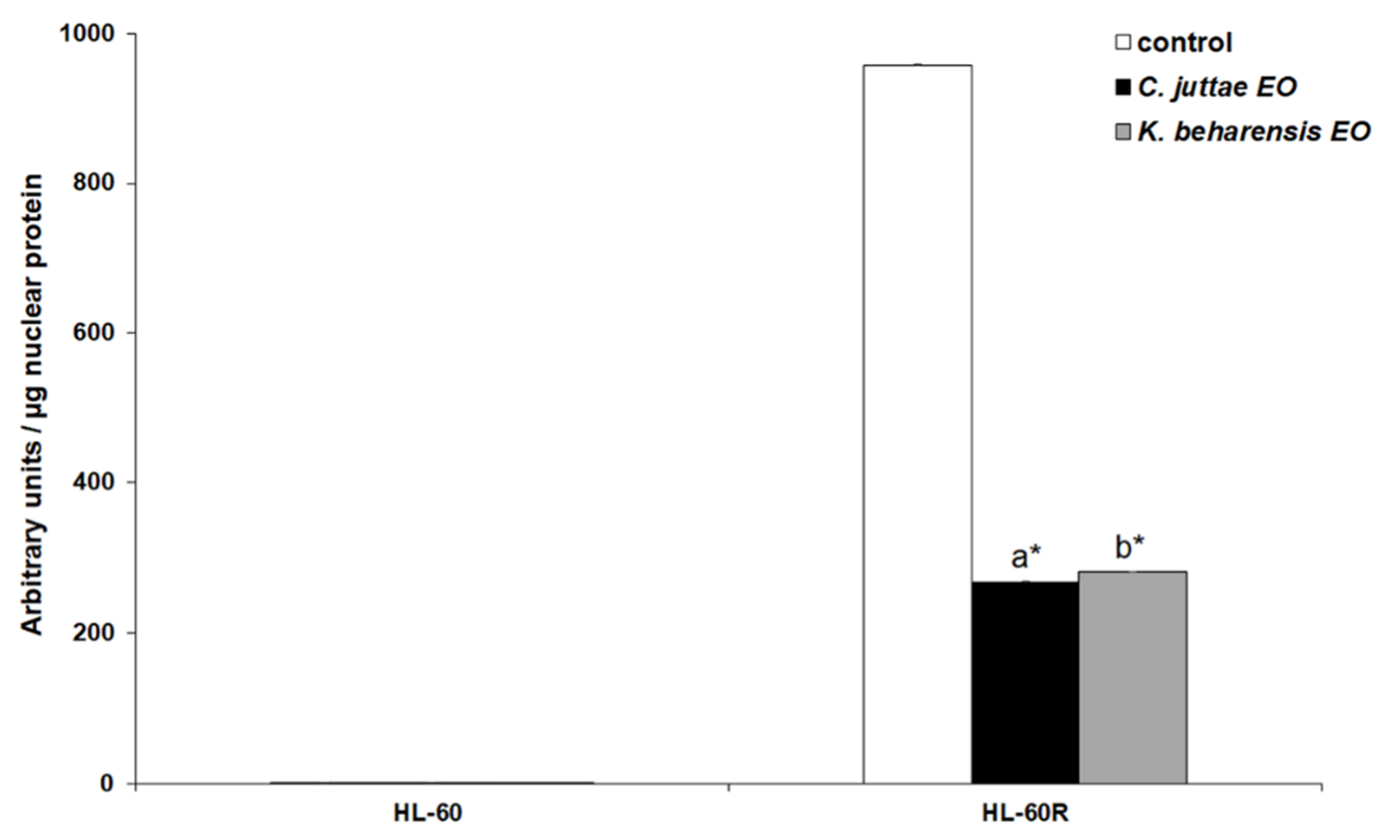

Figure 7. NF- $\mathrm{BB}$ (p65 subunit) DNA binding capacity in nuclear extracts of HL-60 and HL-60R cells.

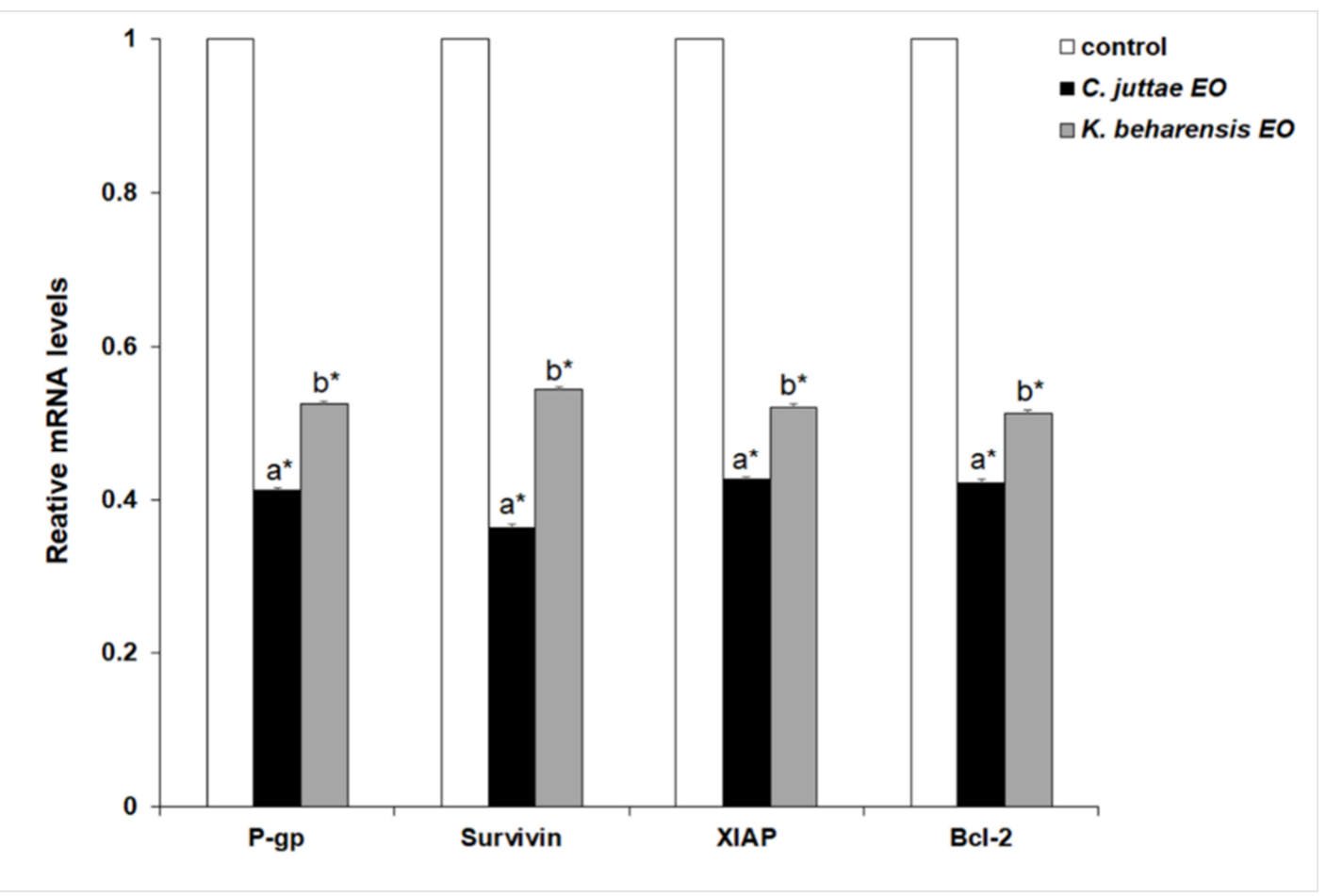

Figure 8. Genes mRNA expression levels by quantitative polymerase chain reaction in HL-60 R cells. 


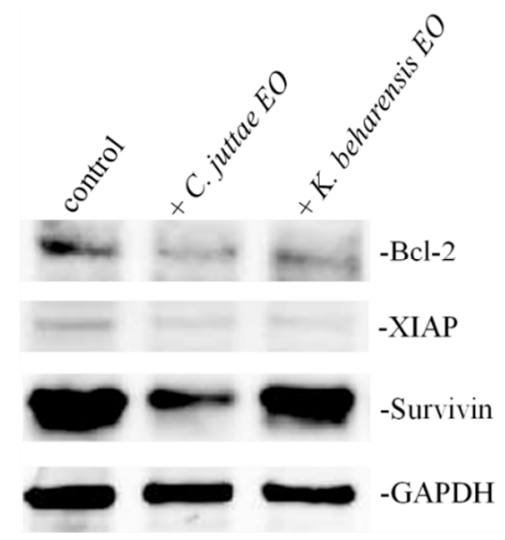

\begin{tabular}{|l|c|c|c|}
\hline HL-60R cells & Bcl-2 & XIAP & Survivin \\
\hline control & $1.33 \pm 0.1$ & $2.1 \pm 0.1$ & $1.5 \pm 0.07$ \\
\hline C. juttae EO & $0.65 \pm 0.03^{* *}$ & $0.5 \pm 0.07^{* *}$ & $0.83 \pm 0.05^{*}$ \\
\hline K. beharensis EO & $0.79 \pm 0.02^{*}$ & $0.83 \pm 0.05^{*}$ & $1.2 \pm 0.07$ \\
\hline
\end{tabular}

Figure 9. Western blotting analysis of the levels of Bcl-2, XIAP and Survivin, in HL-60 R cells treated for $24 \mathrm{~h}$ with $C$. juttae or $K$. beharensis essential oils $(40 \mu \mathrm{g} / \mathrm{mL})$. On the left the results of a representative experiment; on the right, the results expressed as mean \pm standard error of two different experiments. Differences when treatments are compared to the control: ${ }^{*} p<0.05 ;{ }^{* *} p<0.01$.

The cells were treated for $24 \mathrm{~h}$ with $C$. juttae or K. beharensis essential oil $(40 \mu \mathrm{g} / \mathrm{mL})$. Data are expressed as mean \pm standard error of two different experiments. Different letters $(a, b)$ represent significant differences $(p<0.01)$ among the two essential oils for each gene. ${ }^{*}$ Differences when treatments are compared to the control; $p<0.01$.

\section{Discussion}

Terpenes are known as molecules with high biological activities, and there is a wide literature as regards to phytol activities [33]. These compounds are widely present in plants and play a key role in their constitutive defenses [34]. The chemical composition of the two species prompted us to verify if their EOs have comparable activity in the human AML cell line, HL-60, and its multidrug resistant, P-gp over-expressing variant, HL-60R. The two essential oils caused cytotoxicity in HL-60 and noteworthy also on HL-60R cells, regarding cell growth inhibition and induction of cell death. The variant HL-60R was obtained treating HL-60 cells with doxorubicin (for details see Material and Methods section), and its molecular characterization was carried out previously [29,30]. This is an important model of multidrug resistant cancer because HL-60R exhibits resistance to apoptosis induced from numerous drugs, substrates of P-gp, and also from other molecules not related to the multidrug transporter. Furthermore, HL-60R overexpress many IAPs and on the contrary of their parental cell line, HL-60, contained and overexpress p65 subunit that is fundamental to form active transcriptional factor NF-kappaB. The role of this transcriptional factor is well confirmed in numerous types of cancer [35], related to all phases of cancer develop as tumorigenesis, progression, invasion and metastasis, and its overexpression can cause the aberrant expression of the protein responsible of multidrug resistance $[5,36]$. For these reasons, NF- $\mathrm{kB}$ is often studied as a potential target for the treatment of malignant tumors [37-39], including AML [40] for which the therapeutic choice is restricted to few anti-blastic drugs towards which cancer cells develop early resistance. Most recently, new research is being conducted towards checkpoint inhibitors and cancer immunotherapy, like CAR T-cell therapy, but the side effects are multiple and sometimes characterized by unacceptable toxicity [41]. For these reasons, the need for good alternative therapies is urgent. Furthermore, the phenomenon of acquired resistance narrows even more therapeutic possibilities. The most common mechanism for acquisition of resistance is the expression of energy-dependent transporters as ATP binding cassette (ABC) transporters, characterized by homologous ATP-binding, and large, spanning transmembrane domains, including P-gp [1]. In light of this evidence, appears even more significant our result about inhibition of NF-kB activation from essential oils in HL-60 R cells. To further confirm that the transcriptional factor can be an effective pharmacological target, we demonstrated that essential oils produced a significant decrease in many targets of NF- $k B$ both at mRNA and protein levels. 
These targets are just those responsible for resistance to apoptosis induced from drugs (IAPs) and the multidrug transporter, P-gp. We have already reported that, in comparison to HL-60, HL-60R cells exhibit an increased expression of some IAP family members [29,30]. However, different factors involved in apoptosis, such as IAPs can be altered in cancer cells, thereby rendering them less prone to drug-induced cell death. Our results demonstrated that the EOs inhibited the growth and induced cell death by the suppression of signaling of the transcription factor NF- $\mathrm{KB}$ and by the suppression of IAP family proteins and the antiapoptotic factor Bcl-2. We propose, according to the literature $[42,43]$ the fundamental role of NF-kB, P-gp and IAPs as possible therapeutic targets.

Defense in plants is usually constitutive, and they have mechanical or chemical defenses that can discourage and fight phytophagous insects and microorganisms attack. Drugs widely used in the treatment of several human and animal diseases are often chemicals involved in plant defense. Among plants, the chemical compounds of essential oils play a key role in constitutive defense [34,44]. It is interesting to note that the EOs of the two species investigated in the present study interfere with the NF- $\kappa B$ factor. NF- $\kappa B$ is a conservative gene evolved one billion years ago [45] which play a key role in the innate immunity of insects, among others [46]. EOs obtained from some plant species inhibit the constitutive activation of NF-KB expressed in some MDR human cell lines. This mechanism may involve NF- $\mathrm{KB}$ functioning in insects and may explain the selective advantage for plants to produce such compounds which may damage the innate immunity of phytophagous insects and weakening their fitness. The presence of phytol as the major compound in the EOs of C. juttae [11] and K. beharensis (present study) may indicate that this compound is responsible for the NF-kB inhibition.

\section{Material and Methods}

\subsection{Plant Species}

Kalanchoe beharensis Drake (Crassulaceae) is an endemic species of the xerophytic forests of southern Madagascar. This species, reaching about $3 \mathrm{~m}$ in height, has stems with leaves crowded at the branch tips. Since its leaves (12-35 cm long and 7-35 cm wide) are covered in a dense felt it is commonly known as Felt Plant or Elephant Ear [16].

Cyphostemma juttae (Dinter and Gilg) Desc. (Vitaceae) is a tree-like succulent growing in Namibia and it is adapted to dry habitat. Leaves are deciduous and are produced in Summer during the vegetative season.

\subsection{Plant Material}

Leaves of K. beharensis were collected in July 2018 from plants cultivated at the Botanical Garden of the University of Palermo. The plants were raised from seeds in 1984 and cultivated in the open with reference code: Crassulaceae N 39. Leaves of C. juttae were collected in July 2017 at the Botanical garden. The seeds of both species were obtained, and the plants raised before the Convention on Biological Diversity (CBD) entered into force on 29 December 1993, and therefore, are pre-CBD specimens. The matrices were placed in paper bags and kept at $-30^{\circ} \mathrm{C}$ for $24 \mathrm{~h}$ before hydrodistillation. No specific permits were required for the described location and for the collection of plant material because the plants are part of the living collection of the Botanical Garden of the University of Palermo and the authors have access to that.

\subsection{Essential Oil Extraction}

Leaves (507 g) were hand-cut into small pieces $(\sim 2 \mathrm{~cm})$ and hydrodistilled for $3 \mathrm{~h}$ in a Clevenger-type apparatus, using n-pentane as collection solvent [47]. The oil was dried by anhydrous sodium sulphate and stored at $-30^{\circ} \mathrm{C}$ until chemical analysis and pharmacological tests. To prepare the stock solution for biological studies, $2 \mathrm{mg}$ of essential oil was dissolved in $1 \mathrm{~mL}$ of dimethyl sulfoxide (DMSO). C. Juttae EO was obtained from the same batch of Zito et al. [11]. 


\subsection{Gas Chromatography-Mass Spectrometry}

The essential oil of $K$. beharensis was analyzed by GC-MS on a single quadrupole Shimadzu GC-MS-QP2010 Plus equipped with an AOC-20i autoinjector (Shimadzu, Kyoto, Japan) and a Supelcowax 10 capillary column (30 m long, $0.25 \mathrm{~mm}$ i.d., $0.25 \mu \mathrm{m}$ film thickness) (Merck KGaA, Darmstadt, Germany). One $\mu \mathrm{L}$ of diluted samples (1/100 v/v, in n-pentane) was injected at $250{ }^{\circ} \mathrm{C}$ in a split ratio of 1:1, and the column flow (carrier gas: Helium) was set at $1 \mathrm{~mL} / \mathrm{min}$. The GC oven temperature was held for $5 \mathrm{~min}$ at $40^{\circ} \mathrm{C}$, then increased by $2{ }^{\circ} \mathrm{C} / \mathrm{min}$ to $180^{\circ} \mathrm{C}$, held for $60 \mathrm{~min}$ and finally raised to $240{ }^{\circ} \mathrm{C}$ at $10{ }^{\circ} \mathrm{C} / \mathrm{min}$. The MS interface worked at $280^{\circ} \mathrm{C}$, and the ion source at $250{ }^{\circ} \mathrm{C}$. Mass spectra was taken at $70 \mathrm{eV}$ (in EI mode) from m/z 30 to 600. The GC/MS data were analyzed using the GCMSolution package, Version 4.11.

The chemical analysis of $C$. juttae was performed by GC-MS on a Shimadzu GC-MS-QP2010 Ultra equipped with an AOC-20i autoinjector (Shimadzu, Kyoto, Japan) and a ZB-5 fused silica column (30 $\mathrm{m}$ long, $0.32 \mathrm{~mm}$ i.d., $0.25 \mu \mathrm{m}$ film thickness,) as described in detail by Zito et al. [11].

\subsection{Identification of Compounds}

Identification of compounds was carried out using the mass spectral libraries FFNSC 2, W9N11, ESSENTIAL OILS (available in MassFinder 3), and Adams [48]. We only considered compounds which were present in our digital libraries with a calculated Kovats index \pm 10 compared to mass spectra and/or Kovats retention indices found in NIST11, SciFinder and Pherobase [49] database. Kovats retention indices were calculated using a series of n-alkanes $\left(C_{10}-C_{30}\right)$.

\subsection{Cell Lines and Culture Conditions}

The HL-60 cells were obtained from ATCC ${ }^{\circledR}$ (CCL-240, Rockville, MD, USA), while its variant HL-60R, was selected for multidrug resistance (MDR) by exposure to gradually increasing concentrations of doxorubicin. The cells were routinely maintained in Roswell Park Memorial Institute (RPMI) 1640 (HyClone Europe Ltd., Cramlington, UK) supplemented with 10\% heat-inactivated fetal calf serum, $2 \mathrm{mM}$ L-glutamine, 100 units $/ \mathrm{mL}$ penicillin and $100 \mu \mathrm{g} / \mathrm{mL}$ streptomycin (all reagents were from HyClone Europe) in a humidified atmosphere at $37^{\circ} \mathrm{C}$ in $5 \% \mathrm{CO}_{2}$.

\subsection{Cell Growth Inhibition Assays}

The cells were seeded at $1 \times 10^{4}$ cells/well into 96-well plates and then incubated overnight. At time 0, the medium was replaced with complete, fresh medium, and the essential oils were added in various concentrations. After $72 \mathrm{~h}, 15 \mu \mathrm{L}$ of a commercial solution (obtained from Promega Corporation, Madison, WI, USA) containing 3-(4,5-dimethylthiazol-2-yl)-5-(3-carboxymethoxyphenyl)-2-(4-sulphophenyl)-2H-tetrazolium (MTS) and phenazine ethosulfate were added. The plates were incubated for $2 \mathrm{~h}$ in a humidified atmosphere at $37^{\circ} \mathrm{C}$ in $5 \% \mathrm{CO}_{2}$. The bioreduction of the MTS dye was assessed by measuring the absorbance of each well at $490 \mathrm{~nm}$. Cytotoxicity was expressed as a percentage of the absorbance measured in the control cells.

\subsection{Evaluation of Cell Death by Flow Cytometry}

Cells were washed twice with ice-cold PBS and then resuspended at $1 \times 10^{6} / \mathrm{mL}$ in a hypotonic fluorochrome solution containing propidium iodide (PI) $50 \mu \mathrm{g} / \mathrm{mL}$ in $0.1 \%$ sodium citrate plus $0.03 \%$ $(\mathrm{v} / \mathrm{v})$ Nonidet $\mathrm{P}-40$. After $1 \mathrm{~h}$ of incubation in this solution, the samples were filtered through nylon cloth, $40 \mu \mathrm{m}$ mesh, and their fluorescence was analyzed as single-parameter frequency histograms using a FACSort instrument (Becton Dickinson, Mountain View, CA, USA). The data were analyzed with CellQuest $^{\mathrm{TM}}$ (Becton Dickinson, Mountain View, CA, USA). Cell death was determined by evaluating the percentage of events accumulated in the $\mathrm{preG}_{0}-\mathrm{G}_{1}$ position analyzed by flow cytometry. 


\subsection{NF- $\kappa B$ Activation}

The DNA binding capacity of NF-KB (p65 subunit) was measured in the nuclear extracts of cells treated using the TransAM NF- $\mathrm{kB}$ and Nuclear Extract ${ }^{\mathrm{TM}}$ Kits (Active Motif, Carlsbad, CA, USA) according to the manufacturer's instructions and as previously described [11]. The results were expressed as arbitrary units: One unit is the DNA binding capacity shown by $2.5 \mu \mathrm{g}$ of whole cell extract from Jurkat cells stimulated with 12-Otetradecanoylphorbol-13-acetate (TPA)+calcium ionophore $(\mathrm{CI}) / \mu \mathrm{g}$ protein of HL-60/R nuclear extracts.

\subsection{Extraction of Cellular RNA and Reverse Transcription-Quantitative PCR (RT-qPCR)}

Total RNA was extracted from cell lines using TRIzol reagent (Invitrogen Life Technologies, Carlsband, CA, USA). For the evaluation of gene expression, RNA was reverse transcribed using a high capacity complementary DNA (cDNA) reverse transcription kit (Applied Biosystems Life Technologies Inc., Foster City, CA, USA). The resulting cDNAs were subjected to real-time RT-PCR using the TaqMan Gene Expression Master Mix kit (Applied Biosystems Life Technologies Inc., Foster City, CA, USA) in triplicates. The PCR cycling conditions were as follows: Denaturation at $50^{\circ} \mathrm{C}$ for $2 \mathrm{~min}$, annealing at $95^{\circ} \mathrm{C}$ for $10 \mathrm{~min}$, followed by 40 cycles of $95^{\circ} \mathrm{C}$ for $15 \mathrm{sec}$ and extension at $60^{\circ} \mathrm{C}$ for $60 \mathrm{~min}$. The running of the samples and data collection were performed on a StepOne AB Real Time PCR system (Applied Biosystems Life Technologies Inc., Foster City, CA, USA). $\beta$-actin was used as an internal standard. The specific primers used were: Survivin Hs00153353, XIAP Hs00236913, Bcl-2 Hs00236329, ABCB1 Hs00184005 (Applied Biosystems Life Technologies Inc., Foster City, CA, USA). Relative expression was calculated using the comparative $\mathrm{Ct}$ method $[\Delta \mathrm{Ct}=\mathrm{Ct}$ (target gene) - Ct(housekeeping gene)]. Where $\mathrm{Ct}$ was the fractional cycle number at which the fluorescence of each sample passed the fixed threshold. Fluorescence was measured at 515-518 nm using StepOne AB Real Time PCR System software (Applied Biosystems Life Technologies Inc., Foster City, CA, USA). The $\Delta \Delta \mathrm{Ct}$ method was used to determine gene expression levels. $\Delta \Delta \mathrm{Ct}$ was calculated using the formula: $\Delta \Delta \mathrm{Ct}=\Delta \mathrm{Ct}_{\text {(each sample) }}-\Delta \mathrm{Ct}_{\text {(reference sample) }}$. Fold change was calculated using the $2^{-\Delta \Delta C t}$ equation.

\subsection{Western Blot Analysis}

For Western blot analyses, polyclonal rabbit antibody against XIAP was obtained from Cell Signaling Technology Inc., Danvers, MA, polyclonal rabbit antibody against survivin from Abcam Limited, Cambridge, UK; mouse monoclonal antibodies against Bcl-2 were obtained from Santa Cruz Biotechnology Inc., Santa Cruz, CA, USA; monoclonal mouse antibody against GAPDH was obtained from Sigma-Aldrich Srl, Milan, Italy. Whole cellular lysates from HL-60 and HL-60 R cells were obtained using RIPA buffer (Santa Cruz Biotechnology Inc., Santa Cruz, CA, USA) and $15 \mu \mathrm{g}$ of protein were subjected to $10 \%$ SDS-polyacrylamide gel electrophoresis. Proteins were electrophoresed onto nitrocellulose membrane (Amersham, Pharmacia Biotech, Milan, Italy) using a semi-dry fast blot apparatus (Bio-Rad, Milan, Italy). Membranes were blocked with $5 \%$ (w/v) BSA in PBS- $0.1 \%(\mathrm{v} / \mathrm{v})$ Tween 20 for $1 \mathrm{~h}$ and then probed with the anti-XIAP (1:500), anti-survivin (1:2000), anti-Bcl-2 (1:1000), and anti-GAPDH (1:25000) antibodies. Hybridization was visualized using an enhanced chemiluminescence detection kit (SuperSignal West Femto Maximum Sensitivity Substrate, Thermo Scientific Life Technologies Italia, Monza, Italy) and the Versa DOC imaging system (BioRad Laboratories, Milan, Italy). Immunoblots were quantified by densitometry and results were expressed as arbitrary units (protein/GADPH).

Author Contributions: Conceptualization, M.S. and M.N.; Data curation, P.Z., P.P. and M.L.; Formal analysis, M.S., M.N., P.Z., P.P., M.L., A.V.R. and J.A.M.; Funding acquisition, M.N.; Investigation, P.P. and M.L.; Methodology, M.N., P.Z., P.P. and M.L.; Project administration, M.S. and M.N.; Resources, P.Z.; Software, P.Z. and M.L.; Supervision, M.S., M.N., P.P. and J.A.M.; Validation, P.Z. and A.V.R.; Visualization, A.V.R.; Writing一original draft, M.S., M.N., P.Z., P.P. and A.V.R.; Writing-review and editing, M.S., M.N. and J.A.M.

Funding: This work was partially financed by PJ_AUTF_160829_D15 to Monica Notarbartolo. 
Acknowledgments: The authors thank the Director of Palermo Botanic garden, Rosario Schicchi, for allowing access to the living collections. The authors are grateful to Maurizio Bruno and Sergio Rosselli, Department STEBICEF, University of Palermo, Italy for allowing the use of the Shimadzu GC-MS-QP2010 Plus.

Conflicts of Interest: The authors declare no conflict of interest.

\section{References}

1. Szakacs, G.; Paterson, J.K.; Ludwig, J.A.; Booth-Genthe, C.; Gottesman, M.M. Targeting multidrug resistance in cancer. Nat. Rev. Drug Discov. 2006, 5, 219-234. [CrossRef] [PubMed]

2. Choudhuri, S.; Klaassen, C.D. Structure, function, expression, genomic organization, and single nucleotide polymorphisms of human ABCB1 (MDR1), ABCC (MRP), and ABCG2 (BCRP) efflux transporters. Int. J. Toxicol. 2006, 25, 231-259. [CrossRef] [PubMed]

3. Staud, F.; Pavek, P. Breast cancer resistance protein (BCRP/ABCG2). Int. J. Biochem. Cell. Biol. 2005, 37, 720-772. [CrossRef] [PubMed]

4. Gillet, J.P.; Gottesman, M.M. Mechanisms of multidrug resistance in cancer. In Multi-Drug Resistance in Cancer. Methods in Molecular Biology (Methods and Protocols); Zhou, J., Ed.; Humana Press: New York, NY, USA, 2010; Volume 596, pp. 47-76. [CrossRef]

5. Li, Y.; Wang, Y.; Li, L.; Kong, R.; Pan, S.; Ji, L.; Liu, H.; Chen, H.; Sun, B. Hyperoside induces apoptosis and inhibits growth in pancreatic cancer via Bcl-2 family and NF-kappaB signaling pathway both in vitro and in vivo. Tumour Biol. 2016, 37, 7345-7355. [CrossRef] [PubMed]

6. Darwish, N.H.E.; Sudha, T.; Godugu, K.; Bharali, D.J.; Elbaz, O.; El-Ghaffar, H.A.A.; Azmy, E.; Anber, N.; Mousa, S.A. Novel targeted nano-parthenolide molecule against NF-kB in Acute Myeloid Leukemia. Molecules 2019, 24, 2103. [CrossRef] [PubMed]

7. Zhou, J.; Ching, Y.Q.; Chng, W.J. Aberrant nuclear factor-kappa B activity in acute myeloid leukemia: From molecular pathogenesis to therapeutic target. Oncotarget 2015, 6, 5490-5500. [CrossRef] [PubMed]

8. Griessinger, E.; Frelin, C.; Cuburu, N.; Imbert, V.; Dageville, C.; Hummelsberger, M.; Sirvent, N.; Dreano, M.; Peyron, J.F. Preclinical targeting of NF-kB and FLT3 pathways in AML cells. Leukemia 2008, 22, 1466-1469. [CrossRef]

9. Braun, T.; Carvalho, G.; Fabre, C.; Grosjean, J.; Fenaux, P.; Kroemer, G. Targeting NF-kB in hematologic malignancies. Cell. Death Differ. 2006, 13, 748-758. [CrossRef]

10. Poma, P.; Labbozzetta, M.; Notarbartolo, M.; Bruno, M.; Maggio, A.; Rosselli, S.; Sajeva, M.; Zito, P. Chemical composition, in vitro antitumor and pro-oxidant activities of Glandora rosmarinifolia (Boraginaceae) essential oil. PLoS ONE 2018, 13, e0196947. [CrossRef]

11. Zito, P.; Labbozzetta, M.; Notarbartolo, M.; Sajeva, M.; Poma, P. Essential oil of Cyphostemma juttae (Vitaceae): Chemical composition and antitumor mechanism in triple negative breast cancer cells. PLoS ONE 2019, 14, e0214594. [CrossRef]

12. Poma, P.; Labbozzetta, M.; Zito, P.; Alduina, R.; Ramarosandratana, A.V.; Bruno, M.; Rosselli, S.; Sajeva, M.; Notarbartolo, M. Essential oil composition of Alluaudia procera and in vitro biological activity on two drug-resistant models. Molecules 2019, 24, 2871. [CrossRef]

13. Allorge-Boiteau, L. Madagascar centre de spéciation et d'origine du genre Kalanchoe (Crassulaceae). In Biogéographie de Madagascar; Lourenço, W.R., Ed.; Editions de L'ORSTOM: Paris, France, 1996; pp. 137-145.

14. Mackenzie, K.K.; Lütken, H.; Coelho, L.L.; Kaaber, M.D.; Hegelund, J.N.; Müller, R. Kalanchoë. In Ornamental Crops, Handbook of Plant Breeding; Van Huylenbroeck, J., Ed.; Springer: Cham, Switzerland, 2018; Volume 11, pp. 453-479.

15. Descoings, B. Le genre Kalanchoe, structure et définition. In Le journal de Botanique; Le Strat, F., Ed.; Société Botanique de France: Paris, France, 2006; Volume 33, pp. 3-28.

16. Akulova-Barlow, Z. Kalanchoe . Cact. Succ. J. 2009, 81, 268-276. [CrossRef]

17. Yamagishi, T.; Haruna, M.; Yan, X.Z.; Chang, J.J.; Lee, K.H. Antitumor agents, Bryophyllin B, a novel potent cytotoxic bufadienolide from Bryophyllum pinnatum. J. Nat. Prod. 1989, 52, 1071-1079. [CrossRef]

18. Shirobokov, V.P.; Evtushenko, A.I.; Lapchik, V.F.; Shirobokov, D.N.; Suptel, E.A. Antiviral activity of representatives of the family Crassulaceae. Antibiotiki 1981, 26, 897-900.

19. Milad, R.; El-Ahmady, S.; Singab, A.N. Genus Kalanchoe (Crassulaceae): A review of its ethnomedicinal, botanical, chemical and pharmacological properties. Eur. J. Med. Plants 2014, 4, 86. [CrossRef] 
20. Kluge, M.; Razanoelisoa, B.; Ravelomanana, D.; Brulfert, J. In situ studies of crassulacean acid metabolism in Kalanchoe beharensis Drake Del Castillo, a plant of the semi-arid southern region of Madagascar. New Phytol. 1992, 120, 323-334. [CrossRef]

21. Walker, C.C. Two shrubby Madagascan kalanchoes. N.Z. Cactus Succul. J. 2019, 72, 5-9.

22. Nagasaki, M.S. Transmission of Environmental and Conservation Knowledge in Andohahela National Park. Independent Study Project (ISP) Collection 485. 2005. Available online: https://digitalcollections.sit.edu/isp_ collection/485 (accessed on 25 August 2019).

23. Andriamparany, J.N.; Brinkmann, K.; Jeannoda, V.; Buerkert, A. Effects of socio-economic household characteristics on traditional knowledge and usage of wild yams and medicinal plants in the Mahafaly region of south-western Madagascar. J. Ethnobiol. Ethnomed. 2014, 10, 82. [CrossRef]

24. Simmen, B.; Hladik, A.; Ramasiarisoa, P. Food intake and dietary overlap in native Lemur catta and Propithecus verreauxi and introduced Eulemur fulvus at Berenty, Southern Madagascar. Int. J. Primatol. 2003, 24, 949-968. [CrossRef]

25. Gould, L.; Constabel, P.; Mellway, R.; Rambeloarivony, H. Condensed tannin intake in spiny-forest-dwelling Lemur catta, at Berenty Reserve, Madagascar, during reproductive periods. Folia Primatol. 2009, 80, 249-263. [CrossRef]

26. Ghaly, N.S.; Mina, S.A.; Abdel-Aziz, N.F.; Sammour, E.A. Insecticidal activity of the main flavonoids from the leaves of Kalanchoe beharensis and Kalanchoe longiflora. J. Nat. Prod. 2014, 7, 196-202.

27. Teklehaymanot, T.; Giday, M. Ethnobotanical study of medicinal plants used by people in Zegie Peninsula, Northwestern Ethiopia. J. Ethnobiol. Ethnomed. 2007, 3, 12. [CrossRef]

28. Opoku, A.R.; Geheeb-Keller, M.; Lin, J.; Terblanche, S.E.; Hutchings, A.; Chuturgoon, A.; Pillay, D. Preliminary screening of some traditional Zulu medicinal plants for antineoplastic activities versus the HepG2 cell line. Phytother. Res. 2000, 14, 534-537. [CrossRef]

29. Notarbartolo, M.; Cervello, M.; Poma, P.; Dusonchet, L.; Meli, M.; D'Alessandro, N. Expression of the IAPs in multidrug resistant tumor cells. Oncol. Rep. 2004, 11, 133-136. [CrossRef]

30. Notarbartolo, M.; Cervello, M.; Dusonchet, L.; Cusimano, A.; D'Alessandro, N. Resistance to diverse apoptotic triggers in multidrug resistant HL60 cells and its possible relationship to the expression of P-glycoprotein, Fas and of the novel anti-apoptosis factors IAP (inhibitory of apoptosis proteins). Cancer Lett. 2002, 180, 91-101. [CrossRef]

31. Hrdinka, M.; Yabal, M. Inhibitor of apoptosis proteins in human health and disease. Genes Immun. $2019,1$. [CrossRef]

32. Knudsen, J.T.; Eriksson, R.; Gershenzon, J.; Stahl, B. Diversity and distribution of floral scent. Bot. Rev. 2006, 72, 1-120. [CrossRef]

33. Islam, M.T.; Ali, E.S.; Uddin, S.J.; Shaw, S.; Islam, M.A.; Ahmed, M.I.; Chandra Shill, M.; Karmakar, U.K.; Yarla, N.S.; Khan, I.N.; et al. Phytol: A review of biomedical activities. Food Chem. Toxicol. 2018, 121, 82-94. [CrossRef]

34. Dudareva, N.; Negre, F.; Dinesh, A.; Nagegowda, D.A.; Orlova, I. Plant volatiles: Recent advances and future perspectives. Crit. Rev. Plant Sci. 2006, 25, 417-440. [CrossRef]

35. Wu, D.; Wu, P.; Zhao, L.; Huang, L.; Zhang, Z.; Zhao, S.; Huang, J. NF-kappaB expression and outcomes in solid tumors: A systematic review and meta-analysis. Medicine (Baltimore) 2015, 94, e1687. [CrossRef]

36. Rathore, R.; McCallum, J.E.; Varghese, E.; Florea, A.M.; Busselberg, D. Overcoming chemotherapy drug resistance by targeting inhibitors of apoptosis proteins (IAPs). Apoptosis 2017, 22, 898-919. [CrossRef]

37. Fontana, G.; Bruno, M.; Notarbartolo, M.; Labbozzetta, M.; Poma, P.; Spinella, A.; Rosselli, S. Cytotoxicity of oleanolic and ursolic acid derivatives toward hepatocellular carcinoma and evaluation of NF- $\mathrm{B}$ involvement. Bioorg. Chem. 2019, 103054. [CrossRef]

38. Notarbartolo, M.; Labbozzetta, M.; Pojero, F.; D'Alessandro, N.; Poma, P. Potential therapeutic applications of MDA-9/Syntenin-NF-KB-RKIP loop in human liver carcinoma. Curr. Mol. Med. 2018, 18, 630-639. [CrossRef]

39. Poma, P.; Labbozzetta, M.; D'Alessandro, N.; Notarbartolo, M. NF-кB is a potential molecular drug target in triple-negative breast cancers. OMICS 2017, 21, 225-231. [CrossRef]

40. Shen, M.Y.; Wang, Y.; Cui, S.Y.; Wu, X.L.; Guo, Y.; Xu, R.R. MicroRNA-125a regulates proliferation and apoptosis of acute myeloid leukemia through targeting NF-kB pathway. Eur. Rev. Med. Pharmacol. Sci. 2019, 23, 3594-3601. [CrossRef] 
41. Czop, M.; Bogucka-Kocka, A.; Kubrak, T.; Knap-Czop, K.; Makuch-Kocka, A.; Galkowski, D.; Wawer, J.; Kocki, T.; Kocki, J. Imaging flow cytometric analysis of stilbene-dependent apoptosis in drug resistant human leukemic cell lines. Molecules 2019, 24, 1896. [CrossRef]

42. Pan, L.; Li, Y.; Zhang, H.Y.; Zheng, Y.; Liu, X.L.; Hu, Z.; Wang, Y.; Wang, J.; Cai, Y.H.; Liu, Q.; et al. DHX15 is associated with poor prognosis in acute myeloid leukemia (AML) and regulates cell apoptosis via the NF-kB signaling pathway. Oncotarget 2017, 8, 89643-89654. [CrossRef]

43. Zhou, J.; Lu, X.; Tan, T.Z.; Chung, W.J. X-linked inhibitor of apoptosis inhibition sensitizes acute myeloid leukemia cell response to TRAIL and chemotherapy through potentiated induction of proapoptotic machinery. Mol. Oncol. 2018, 12, 33-47. [CrossRef]

44. Regnault-Roger, C.; Vincent, C.; Arnason, J.T. Essential oils in insect control: Low-risk products in a high-stakes world. Annu. Rev. Entomol. 2012, 57, 405-424. [CrossRef]

45. Gilmore, T.D.; Wolenski, F.S. NF-кB: Where did it come from and why? Immunol. Rev. 2012, 246, 14-35. [CrossRef]

46. Silverman, N.; Maniatis, T. NF-кB signaling pathways in mammalian and insect innate immunity. Genes Dev. 2001, 15, 2321-2342. [CrossRef]

47. Zito, P.; Sajeva, M.; Bruno, M.; Rosselli, S.; Maggio, A.; Senatore, F. Essential oils composition of Periploca laevigata Aiton subsp. angustifolia (Labill.) Markgraf (Apocynaceae-Periplocoideae). Nat. Prod. Res. 2013, 27, 255-265. [CrossRef]

48. Adams, R.P. Identification of Essential Oil Components by Gas Chromatography/Mass Spectroscopy, 4th ed.; Allured Publishing: Carol Stream, IL, USA, 2007.

49. El-Sayed, A.M. The Pherobase: Database of Insect Pheromones and Semiochemicals. Available online: http://www.pherobase.com/ (accessed on 10 June 2019).

(C) 2019 by the authors. Licensee MDPI, Basel, Switzerland. This article is an open access article distributed under the terms and conditions of the Creative Commons Attribution (CC BY) license (http://creativecommons.org/licenses/by/4.0/). 